\title{
PENINGKATAN MINAT DAN HASIL BELAJAR BILANGAN BERPANGKAT DAN BENTUK AKAR SISWA KELAS X TEKNIK SEPEDA MOTOR SMK ELEKTRO SIJUNJUNG DENGAN MENGGUNAKAN PETA KONSEP
}

\author{
Dewi Sefriyanti \\ Mahasiswa S2 Pendidikan Matematika PPS Universitas Negeri Padang \\ Email dewisefriyanti48@yahoo.co.id
}

\begin{abstract}
This study aims to increase students' interest and mathematics learning achievements on the subject of rank numbers, root shapes and logarithms. In this study I used a concept map. Concept maps are a tool in the form of a scheme that states the relationship between concepts starting from the general to the specific ones which are connected through arrows in the form of propositions. Proposition is two or more statements about a concept that are related to words or arrows.

Concept maps play an important role in meaningful learning, with concept maps of students being trained to think, in students being asked to think about concepts or events they already know. Meaningful learning is easier to take place if new concepts are linked to concepts that are inclusive, inclusive concepts that are basic concepts that are more general in nature. Concept maps must be arranged in a hierarchical manner, which means that a more inclusive concept is at the top of the map, the concepts below are sorted into less inclusive ones.
\end{abstract}

Keywords: Concept maps, propositions, concepts, rank numbers, root shapes, logarithms

\begin{abstract}
ABSTRAK
Penelitian ini bertujuan untuk meningkatkan minat dan prestasi belajar matematika siswa pada pokok bahasan bilangan berpangkat, bentuk akar dan logaritma. Pada penelitian ini saya menggunakan peta konsep.Peta konsep adalah suatu alat berupa skema yang menyatakan hubungan antara konsep-konsep yang dimulai dari hal umum ke yang khusus yang dihubungkan melalui bentuk panah dalam bentuk propsisi. Proposisi merupakan dua atau lebih pernyataan tentang suatu konsep yang dihubungkan dengan kata atau bentuk panah.

Peta konsep memegang peranan penting dalam belajar bermakna, dengan peta konsep siswa dilatih berfikir, pada siswa diminta untuk memikirkan konsep-konsep atau kejadian yang telah mereka ketahui. Belajar bermakna lebih mudah berlangsung bila konsep-konsep baru dikaitkan pada konsep-konsep yang inklusif, konsep inklusif yaitu konsep pokok yang sifatnya lebih umum. Peta konsep harus disusun secara hirarki, ini berarti konsep yang lebih inklusif ada di puncak peta, makin kebawah konsep-konsep itu diurutkan menjadi yang kurang inklusif.

Kata Kunci: Peta konsep, proposisi, konsep, bilangan berpangkat, bentuk akar, logaritma
\end{abstract}




\section{PENDAHULUAN}

Ilmu pengetahuan dan teknologi (IPTEK) memegang peranan penting dalam perkembangan peradaban dan kehidupan manusia. Agar manusia dapat menguasai IPTEK, maka sangat diperlukan proses pendidikan yang berkualitas. Salah satu cara untuk meningkatkan mutu pendidikan adalah dengan memperbaiki pembelajaran di sekolah pada semua bidang studi. Proses pembelajaran akan berhasil selain ditentukan oleh kemampuan guru dalam menentukan metode yang digunakan dalam pembelajaran, juga ditentukan oleh minat belajar siswa.

Berbagai usaha dilakukan pemerintah untuk meningkatkan mutu pendidikan seperti pembaruan kurikulum, peningkatan kemampuan guru, pengadaan buku ajar, melengkapi sarana dan prasarana pendidikan. Peningkatan dilakukan untuk seluruh bidang studi termasuk bidang studi matematika. Walaupun demikian kita dihadapkan pada masalahnya rendahnya hasil belajar siswa sehingga menyebabkan rendahnya mutu pendidikan dan minat belajar siswa. Salah satu kemungkinan penyebanya karena mereka menganggap matematika itu merupakan pelajaran yang sulit dan sangat membingungkan.

Berdasarkan pengalaman peneliti guru matematika SMK ELEKTRO Kab. Sijunjung terungkap bahwa rendahnya hasil belajar matematika disebabkan karena sebagian besar siswa kurang termotivasi untuk belajar matematika. Hal ini disebabkan karena siswa menganggap bahwa matematika itu adalah pelajaran yang sulit dan menakutkan. Menurut Sujono (2004:337) menyatakan bahwa pada dua dasa warsa ini rendahnya hasil belajar matematika mungkin disebabkan oleh ketakutan siswa pada matematika. Apabila mereka akan ujian mereka cenderung menghafal rumus-rumus tersebut tanpa mengerti makna yang terkandung dari rumus-rumus tersebut. Kedaan ini selain menyulitkan siswa dalam memahami konsep juga dapat mempengaruhi hasil belajar siswa. Hal seperti ini selain menyulitkan siswa dalam memahami konsep dan menghubungkan konsep-konsep yang relevan juga dapat mempengaruhi hasil belajar siswa.

Untuk mengatasi keadaan di atas, perlu strategi mengajar yang sesuai agar siswa mampu menguasai dan memahami konsep-konsep. Selama ini usaha yang telah dilakukan guru khususnya guru matematika kelas X SMK ELEKTRO Kab. Sijunjung adalah dengan memperbanyak pemberian latihan agar siswa terampil menggunakan rumus dan dapat mengingatkannya lebih lama, untuk memperdalam pemahaman siswa terhadap materi yang diajarkan guru memberikan tugas di rumah dan dibahas pada pertemuan selanjutnya.

Salah satu alternatif yang dapat dilakukan guru agar siswa belajar lebih bermakna adalah dengan menggunakan peta konsep. Melalui peta konsep dapat diperlihatkan bagaimana konsep itu saling berkaitan satu sama lainnya, sehingga dengan adanya peta konsep siswa dapat "melihat" materi pelajaran itu lebih jelas dan mempelajarinya lebih bermakna Bila guru telah menyelesaikan suatu konsep dari materi pelajaran yang akan 
diajarkan dan menyusunnya serta menggunakannya dalam proses pembelajaran, maka ia telah berusaha agar konsep-konsep yang diajarkan saling berkaitan sehingga dapat membantu siswa untuk memahami konsep tersebut dan dengan sendirinya akan timbul kebermaknaan dari pelajaran itu.

Berdasarkan pengalaman penulis bahwa di dalam matematika bila konsep A dan konsep $\mathrm{B}$ mendasari konsep $\mathrm{C}$, maka konsep $\mathrm{C}$ tidak mengkin dipelajari sebelum konsep A dan konsep B dipahami terlebih dahulu. Demikian pula konsep D baru dapat dipelajari bila konsep $\mathrm{C}$ sudah dipahami, demikian seterusnya. Karena kehirarkian matematika itu, maka belajar matematika yang terputus-putus akan mengganggu terjadinya proses belajar, atau dengan kata lain proses belajar mengajar akan lancar jika belajar itu sendiri dilakukan secara kontiniu.

Pengajaran matematika haruslah menekankan kepada pengertian konsep-konsep dan struktur matematika, serta belajarnya melalui pemecahan masalah. Jika pengertian suatu konsep sudah dipahami, maka setealah itu keterampilan perlu diperoleh melalui latihan. Setelah keterampilan melalui latihan tercapai diharapkan siswa dapat mengingat konsep-konsep lebih baik. Jadi yang diperlukan sebagai dasar dalam pemecahan masalah adalah mengorganisasikan ingatan tentang konsep-konsep matematika sedemikian rupa sehingga konsep-konsep tersebut dapat digunakan dalam penyelesaian masalah secara efektif.

Agar diperoleh hasil belajar yang diinginkan, maka guru harus berusaha semaksimal mungkin supaya materi yang disajikan dapat dikuasai oleh siswa. Seperti yang dikemukakan oleh Rohmad (2008:2). Bahwa:"Guru menerapkan berbagai metode yang dipandang sesuai dengan bahasan materi matematika yang sedang dipelajari, siswa terlibat membangun ide-ide, konsep-konsep, prinsip-prinsip dan struktur-struktur matematika berdasarkan pengalaman sendiri”.

Guru hendaklah menolong siswanya dalam mengingat dan mengaitkan materi yang diberikan sebelumnya dengan materi baru. Hal ini akan membantu siswa untuk dapat mengingat materi pelajaran lebih bermakna.

Berdasarkan uraian di atas jelaslah bahwa belajar dan mengajar merupakan dua kegiatan, namun satu kesatuan yang tidak dapat dipisahkan antara satu dengan lainnya, "Belajar mengajar itu dua kegiatan yang saling mempengaruhi yang dapat menentukan hasil belajar".

Menurut Ausubel belajar dapat diklasifikasikan dalam dua dimensi. Dimensi pertama berhubungan dengan cara informasi atau materi pelajaran itu disajikan kepada siswa, melalui metode penerimaan atau metode penemuan. Pada belajar metode penerimaan informasi disajikan dalam bentuk final, sedangkan belajar melalui penemuan siswa yang menemukan sebagian atau seluruh informasi itu. Selanjutnya dimensi kedua menyangkut bagaimana siswa dapat mengaitkan informasi pada struktur kognitif yang ada. Jika siswa hanya mencoba menghafalkan informasi baru itu tanpa menghubungkan dengan struktur kognitifnya, maka terjadilah belajar dengan hafalan, sebaliknya jika siswa menghubungkan atau mengaitkan informasi baru itu dengan struktur kognitifnya maka yang terjadi adalah belajar bermakna. 
Dari uraian di atas dapat diambil pengertian bahwa belajar dengan menggunakan metode penemuan maupun metode penerimaan dapat menghasilkan belajar yang bermakna maupun belajar dengan hafalan. Inti teori Ausubel tentang belajar adalah belajar bermakna, yaitu suatu proses mengaitkan informasi baru pada konsep-konsep yang relevan dalam struktur kognitif seseorang.

Berdasarkan teori Ausubel tentang belajar bermakna menyimpulkan kondisikondisi belajar bermakna berikut:

1) Menjelaskan hubungan atau relevasi bahan-bahan baru dengan bahan-bahan lama.

2) Lebih dahulu diberikan ide yang paling umum dan kemudian hal-hal yang lebih terpirinci, yang disebut diferensiasi progresi

3) Menunjukan persamaan dan perbedaan antara bahan baru dan bahan yang lama

4) Mengusahakan agar ide yang telah ada dikuasai sepenuhnya sebelum ide yang baru disajikan.

Ausubel sangat menekankan bahwa penting bagi guru untuk mengetahui konsep yang telah dimiliki siswa, maka salah satu cara bagi guru untuk mengetahui sejauh mana konsep yang dimiliki siswa dan agar konsep-konsep yang diajarkan selalu berkaitan serta tidak terlepas-lepas adalah dengan menggunakan teknik pemetaan konsep. Alat yang digunakan untuk menyatakan kegiatan atau hubungan yang bermakna antara konsep-konsep itu disebut dengan "Peta Konsep"

Konsep merupakan dasar untuk berpikir, untuk belajar aturan-aturan dan akhirnya untuk memecahkan masalah, Dahar dalam Holil (2008:2), ini berarti konsep merupakan dasar bagi proses mental yang lebih tinggi untuk merumuskan prinsip-prinsip generalisasi maupun untuk memecahkan masalah.

Bila dikaitkan dengan matematika maka konsep adalah ide abstrak yang dapat digunakan untuk menggolongkan atau mengklasifikasikan sekumpulan objek (Wartono Dkk, 2004:10). Karena konsep matematika bersifat abstrak maka dalam mengajarkannya tidak cukup hanya dengan memberikan defenisi saja, tapi yang lebih penting bagaimana agar siswa dapat memahami dan akhirnya dapat mengaplikasikan ke berbagai permasalahan. Sebagaimana yang dikemukakan oleh Bruner dalam Zubir (2000:10) bahwa belajar matematika akan berhasil jika proses penajaran diarahkan kepada konsep-konsep dan struktur-struktur yang terdapat dalam pokok bahasan yang akan diajarkan

Dengan demikian konsep-konsep ini akan menimbulkan suasana belajar yang bermakna. Apabila struktur-struktur isi pelajaran ditata sedemikian rupa dan berkaitan langsung dengan kebutuhan peserta didik serta disajikan dalam kondisi pembelajaran yang mengesankan maka akan timbul pemebelajaran yang bermakna 


\section{METODOLOGI PENELITIAN}

Subyek dalam PTK ini adalah siswa kelas X TSM SMK ELETRO Sijunjung tahun pelajaran 2017/2018. Penentuan kelas ini dilaksanakan peneliti berdasarkan hasil investigasi terhadap kelas yang diajar oleh peneliti .Peneliti memprediksi bahwa kelas ini akan terjadi permasalahan rendahnya minat dalam pembelajaran matematika. Peneliti memprediksi akan terjadi peningkatan hasil belajar matematika tentang bilangan berpangkat, bentuk akar, dan logaritma jika dilakukan dengan metode pta konsep melalui kegiatan diskusi,observasi.

Penelitian ini dilaksanakan selama 8 minggu sejak mulai kegiatan persiapan hingga pelaksanaan tindakan, PTK dilaksanakan di kelas X TSM SMK ELEkTRO Sijunjung tahun pelajaran 2017/2018 karena peneliti mengajar di kelas tersebut. Prosedur penelitian meliputi kegiatan sebelum pelasanaan PTK dilanjutkan dengan pelaksanaan PTK direncanakan selama dua siklus.

Penelitian ini rencana akan dilaksanakan dua siklus. Persiapan dimulai pada bulan juni, pelaksanaan pada bulan juli dan laporan dimulai bulan awal september. Hasil refleksi siklus I digunakan sebagai acuan dalam menentukan perbaikan tindakan pada siklus II. Sedangkan hasil refleksi siklus I nantinya digunakan sebagai acuan untuk rencana tindak lanjut pada pembelajaran selanjutnya.

Peta konsep memegang peranan penting dalam belajar bermakna, dengan peta konsep siswa dilatih berfikir, pada siswa diminta untuk memikirkan konsep-konsep atau kejadian yang telah mereka ketahui. Belajar bermakna lebih mudah berlangsung bila konsep-konsep baru dikaitkan pada konsep-konsep yang inklusif, konsep inklusif yaitu konsep pokok yang sifatnya lebih umum. Peta konsep harus disusun secara hirarki, ini berarti konsep yang lebih inklusif ada di puncak peta, makin kebawah konsep-konsep itu diurutkan menjadi yang kurang inklusif.

\section{HASIL DAN PEMBAHASAN}

Pembelajaran Siklus I dilaksanakan dengan menggunakan metode konvesional, (metode ceramah dan tanya jawab tanpa menggunakan Peta konsep). Siklus ini terdiri dari Penyusunan rencana, tindakan, observasi, dan refleksi. Pada siklus pertama, proses pembelajaran direncanakan dilaksanakan dalam 4 kali pertemuan. Secara umum seluruh siswa mengikuti pelajaran dengan baik dan tertib dan sebagian besar siswa nampak tertarik dengan metode, materi dan cara penyampaian materi yang lain dari biasanya, siswa selalu dilibatkan serta siswa nampak lebih senang belajar dalam kelompok.

Siklus kedua direncanakan dilaksanakan dalam 4 kali pertemuan. Langkahlangkahnya tetap sama, hanya ada penekanan tindakan seperti siswa yang mengatakan "dengan peta konsep tambah pusing" didekati dan dibimbing tersendiri. Waktu kerja kelompok lebih dipantau lagi supaya tidak ada siswa yang tidak mau bekerja lagi. Siswa melaksanakan tugas dengan baik, kelas terkendali, tertib dan lancar. Siswa nampak menikmati pembelajaran dengan metode ini, terbukti lebih banyak siswa yang membawa pewarna lebih banyak daripada 
Berdasarkan pembahasan hasil penelitian di atas dapat ditarik kesimpulan, bahwa penggunaan peta konsep dapat menarik minat siswa dalam belajar matematika dan memahami konsep-konsep keterkaitannya.

\section{SIMPULAN}

Berdasarkan penelitian yang telah dilakukan, maka di peroleh hasil Setelah pembelajaran dengan metode peta konsep dilaksanakan, peneliti mengambil kesimpulan sebagai berikut :

1) Metode peta konsep sangat diperlukan dalam pembelajaran matematika. Dengan membuat kerangka sub topik dalam bentuk peta konsep yang dapat digambari dan diwarnai sesuka hati, dapat memotivasi siswa untuk mengekspresikan gagasannya melalui gambar yang beraneka ragam dan warna. Peta konsep juga dapat memunculkan ide, sehingga mempermudah siswa dalam memahami akan keterkaitan konsep. Selain itu, peta konsep juga dapat memunculkan kreatifitas siswa kelas X Teknik Sepeda Motor SMK ELEKTRO

2) Implementasi metode peta konsep dalam pembelajaran menumbuhkan minat siswa belajar matematika. Hal ini dibuktikan dengan catatan hasil pengamatan peneliti, yang memberi catatan bahwa siswa sangat senang atau antusias dalam mengikuti pelajaran dengan metode peta konsep. Siswa juga sangat aktif dalam mengikuti pelajaran. Penampilan guru dan materi yang disajikan cukup baik, mengena dan mudah diterima siswa. Pada waktu ulangan, semua siswa terlihat asyik dalam mengerjakan tugas dan semua siswa dapat menyelesaikan tugas itu dengan baik.

\section{DAFTAR PUSTAKA}

Abdul Aziz, Hamka. 2016. Karakter Guru Profesional Melahirkan Murid Unggul Menjawab Tanntangan Masa Depan. Jakarta Selatan: Al mawardi Prima

Arikunto, Suharsimi. 2002. Dasar-Dasar Evaluasi Pendidikan. Jakarta: Bumi Aksara 2002. Manajemen Penelitian. Jakarta: Rineka Cipta

Agusrini, Fitri. 2004. Studi Tentang Pembelajaran Matematika Siswa Dengan Menggunakan Peta Konsep. Padang:FMIPA UNP

Ahmadi, Abu. 2001. Psikologi Belajar. Jakarta: Rineka Cipta

Depdiknas. 2008. Buku Pedoman Analisis Hasil Belajar. Jakarta: Dirjen Dikdasmen Hamalik. Oemar. 2001. Proses Belajar Mengajar. Bandung: Bumi Aksara

2002. Pendidikan Guru Berdasarkan Pendekatan Kompetensi. Jakarta: Bumi Aksara

Holil, Anwar. 2008. Mempermudah Konsep Sulit Menjadi Mudah dalam Pembelajaran dengan Menggunakan Peta Konsep (online), vol.1, (http://rochmad-unnesblogspot.com/2008/01/16/penggunaan-pola-pikir-induktif-deduktif.htm, diakses 03 November 2008

Ghony, M. Djunaidi dkk. 2016. Metodologi Penelitian Kualitatif. Jogjakarta: Ar-Ruzz Media 
Rochmad. 2008. Penggunaan pola pikir Induktif-deduktif dalam pembelajaran matematika beracuan konstruktivisme (online), vol 1. (http://rochmad-unnesblogspot.com/2008/01/16/penggunaan-pola-pikir-induktif-deduktif-htm, diakses 03 november 2008

Supriyadi. 2011. Strategi BelajarMengajar. Yogyakarta:Cakrawala Ilmu Suryabrata, Sumadi. 2000. Metode Penelitian. Jakarta: Raja Grafindo Persada 2004. Psikologi Pendidikan, Jakarta: Raja Grafindo Persada Tim Penulis. 2004. Buku Panduan Penulisan Tesis dan Disertasi. Padang: UNP Zubir, Sabri. 2000. Makalah Strategi Belajar Mengajar Matematika. Padang Zainurie. 2007. Pembelajaran matematika realistik (online), vol 1, (http://zaimurie.wordpress.com,2007/04/13/pembelajaran-matematikarealistik-rme/, diakses 03 November 2008 